\title{
PENGARUH PUPUK UREA TERHADAP HASIL TANAMAN JAGUNG YANG DITUMPANGSARIKAN DENGAN KACANG TANAH
}

\author{
Af Idatim Masruroh, Herawati Hamim, Niar Nurmauli \\ Jurusan Agroteknologi, Fakultas Pertanian Universitas Lampung \\ Jl. Prof. Soemantri Brodjonegoro, No.1, Bandar Lampung 35145 \\ E-mail: Afidatimmasruroh@yahoo.com
}

\begin{abstract}
ABSTRAK
Penelitian bertujuanuntukmengetahui (1) hasil tanaman yang lebih tinggi antara tanaman yang ditumpangsarikan dengan tanaman monokultur; dan (2) menentukan dosis pupuk Urea yang optimum untuk tumpangsari jagung dengan kacang tanah. Penelitian dilaksanakan pada bulan Agustus hingga Desember 2014 di Lapang Terpadu dan Laboratorium Agronomi Fakultas Pertanian Universitas Lampung.Rancangan yang digunakan adalah rancangan kelompok teracak sempurna (RKTS) dengan sembilan perlakuan yaitu monokultur jagung, monokulturkacang tanah, tumpangsari jagung dengan kacang tanah pada dosis urea untuk tanaman jagung 0 (P3), 50 (P4), 100 (P5), 150 (P6), 200 (P7), 250 (P8) dan 300 (P9) kg/ha. Perbedaan antar perlakuan diuji dengan uji ortogonal pada taraf $\alpha 0,05$. Hasil penelitian menunjukkan bahwa (1) hasil tanaman monokultur lebih tinggi daripada hasil tanaman tumpangsari. Rata-rata hasil tanaman jagung yang ditanam secara tumpangsari yaitu 1,69 t/ha dan tanaman kacang tanah yang ditumpangsarikan rata-ratanya yaitu $0,42 \mathrm{t} / \mathrm{ha}$, tanaman jagung yang ditanam secara monokultur hasilnya 2,61 t/ha dan hasil kacang tanah yang ditanam monokultur yaitu 1,07 t/ha. Hasil tumpangsari tertinggi yaitu pada pemupukan urea $300 \mathrm{~kg} / \mathrm{ha}$ dengan hasil jagung 2,57 t/ha dan kacang tanah 0,46 t/ha, (2) belum diperoleh dosis pupuk urea yang optimum untuk jagung yang ditumpangsarikan dengan kacang tanah.
\end{abstract}

Kata kunci :tumpangsari, jagung, kacang tanah, urea.

\section{PENDAHULUAN}

Jagung merupakan tanaman pangan penting di Indonesia, namun penurunan luas panen jagung menyebakan hasil jagung terus menurun. Hal tersebut menyebabkan perlu dilakukan teknik budidaya yang baik, agar hasil tanaman jagung dapat tetap tinggi walaupun terjadi penurunan luas lahan tanam.Teknik budidaya tanaman dapat dilakukan dengan menanan secara monokultur dan tumpangsari. Nafziger (2007) menyebutkan bahwa monokultur merupakan cara tanam dengan menanam satu tanaman pada satu lahan, sedangkan tumpangsari adalah penanaman dua atau lebih tanaman pada lahan dan waktu yang sama sehingga hasil tanaman dapat melengkapi antara satu dan yang lain.

Warsana (2009), menyebutkan bahwa pola tanam tumpangsari memiliki banyak keuntungan diantaranya populasi tanaman dapat diatur sesuai yang dikehendaki, pada satu areal diperoleh produksi lebih dari satu komoditas, tetap mempunyai peluang mendapatkan hasil manakala satu jenis tanaman yang diusahakan gagal, dan kombinasi beberapa jenis tanaman dapat menciptakan stabilitas biologi sehingga dapat menekan serangan hama dan penyakit serta mempertahankan kelestarian sumber daya lahan dalam hal ini kesuburan tanah. Menurut Gliessman (2007) tumpangsari baik dilakukan pada lahan dengan luasan 1,5- 2 ha. Sehingga tumpangsari lebih dianjurkan untuk lahan sempit, hal ini berkorelasi positif dengan kepemilikan lahan masyarakat Indonesia.

Sumarno dan Unang (2010) menyatakan bahwa kurang dari $1 \%$ masyarakat Indonesia yang memiliki luas lahan lebih dari 10 ha, rata-rata masyarakat Indonesia hanya memiliki lahan pertanian sebanyak 0,30,7 ha. Selain pola tanam yang dilakukan, untuk meningkatkan produksi tanaman juga dapat dilakukan dengan menambahkan unsur hara pada tanaman atau dilakukan pemupukan. Pemilihan jenis pupuk yang akan digunakan ditentukan oleh jumlah dan kandungan hara yang terdapat dalam pupuk, pengaruh terhadap kualitas tanaman, penentuan dosis pupuk, penentuan kebutuhan pupuk dan rekomendasi pemupukan, serta waktu aplikasi pemupukan (Gofar, 2015). Menurut Muyassir (2013), salah satu hara makro yang dibutuhkan tanaman jagung selama siklus hidupnya adalah hara nitrogen. Sumber hara tersebut dapat berasal dari pupuk sintetis seperti urea, ZA dan lain-lain. Nitrogen adalah salah satu dari unsur penting untuk pertumbuhan tanaman, yang berfungsi tidak hanya meningkatkan pertumbuhan 
tanaman tetapi juga sebagai unsure pembentuk protein (Zhang dkk, 2012).

Tumpangsari tanaman juga dapat digunakan untuk penambahan unsur $\mathrm{N}$ pada tanah, terutama tumpangsari dengan Leguminaceae (kacang-kacangan). Hal ini karena kacang-kacangan pada akarnya terdapat bintil akar yang dapat bersimbiosis dengan bakteri Rhizobium $s p$., yang dapat memfiksasi $\mathrm{N}_{2}$ bebas dari udara. Sehingga pola tanam tumpang sari dapat mengurangi penggunaan pupuk urea secara tidak langsung dan bisa meningkatkan hasil Jagung dan Kacang Tanah. Penelitian ini bertujuan untuk mengetahui hasil tanaman yang lebih tinggi antara tanaman yang ditumpangsarikan dengan tanaman monokultur dan menentukan dosis pupuk yang optimum untuk tumpangsari jagung dengan kacang tanah.

\section{BAHAN DAN METODE}

Penelitian dilaksanakan pada bulan Agustus hingga Desember 2014 di Lapang Terpadu dan Laboratorium Agronomi Fakultas Pertanian Universitas Lampung. Percobaan disusun dengan rancangan kelompok teracak sempurna (RKTS) dengan sembilan perlakuan yang diulang tiga kali. Perlakuan terdiri dari monokultur jagung (P1), monokultur kacang tanah (P2) dan tumpangsari dengan dosis urea $0(\mathrm{P} 3), 50(\mathrm{P} 4), 100(\mathrm{P} 5)$, 150 (P6), 200 (P7), 250 (P8) dan 300 (P9) kg/ha. Jarak tanam pada monokultur jagung yaitu $20 \times 75 \mathrm{~cm}$, monokultur kacang tanah 20 × 37,5 cm dan tumpangsari anatara jagung dan kacang tanah yaitu $20 \times 37,5 \mathrm{~cm}$. Homogenitas ragam diuji dengan uji Barlett dan kemenambahan data diuji dengan uji Tukey. Jika asumsi terpenuhi, maka data dianalisis dengan sidik ragam dan apabila hasil uji $\mathrm{F}$ nyata selanjutnya dilakukan uji perbandingan ortogonal pada taraf nyata $5 \%$ (Tabel 1).

Komponen hasil jagung yang diamati yaitu umur bunga penuh tanaman jagung, panjang tongkol jagung, diameter tongkol jagung, bobot 100 butir jagung dan hasil jagung. Komponen kacang tanah yang diamati yaitu jumlah cabang produktif kacang tanah, jumlah polong total, jumlah polong isi, bobot 100 butir dan hasil kacang tanah. Dilakukan analisis tanah sebelum penelitian untuk kandungan $\mathrm{N}, \mathrm{P}, \mathrm{K}$ dalam tanah dan nilai $\mathrm{pH}$ tanah, setelah penelitian dilakukan analisis tanah untuk kandungan $\mathrm{N}$, dan pengamatan curah hujan untuk data pendukung.

\section{HASIL DAN PEMBAHASAN}

Komponen hasil jagung. Hasil penelitian menunjukkan bahwa tumpangsari jagung dan kacang tanah tidak berpengaruh terjadap umur bunga penuh tanaman jagung, panjang tongkol jagung dan diameter tongkol jagung. Tumpangsari jagung dan kacang tanah berpengaruh terhadap bobot 100 butir jagung dan hasil jagung.

Pola tanam monokultur dan tumpangsari tidak berbeda pada umur bunga penuh, panjang tongkol dan diameter tongkol jagung. Diduga umur muncul bunga dan diameter tongkol tanaman dipengaruhi oleh faktor genetik sehingga tumpangsari dan pemberian pupuk urea tidak berpengaruh terhadap umur muncul bunga. Hal ini sejalan dengan hasil penelitian Ezward (2010) yang menyatakan bahwa hasil analisis ragam menunjukkan pada pola tanam secara tumpang sari, dua varietas jagung memberikan pengaruh tidak nyata terhadap umur muncul bunga. Selain itu, menurut Amjadian dkk (2013) tumpangsari tanaman tidak memiliki efek yang penting pada sifat diameter tongkol jagung.

Pola tanam monokultur dan tumpangsari berbeda pada pengamatan bobot 100 butirjagung. Bobot 100 butir jagung yang ditanam secara tumpangsari lebih tinggi dari bobot 100 butir jagung yang ditanam secara monokuktur. Hal ini sejalan dengan hasil penelitian Sarjito dan Hartanto (2007) yang menyebutkan bahwa pada bobot 100 butir dan indeks panen, pengaruh pemupukkan nitrogen bergantung pada ada tidaknya penyisipan kedelai. Bobot 100 biji jagung tidak berbeda pada saat ditanam secara monokultur, namun pada saat disisipi kedelai bobot 100 biji meningkat sejalan dengan peningkatan dosis pupuk nitrogen. Tongkol tanaman jagung yang ditanam secara monokultur hasinya lebih baik dari tongkol tanaman dari hasil tumpangsari.

Tabel 1. Koefisien ortogonal dan ortogonal polinomial untuk jagung dan kacang tanah

\begin{tabular}{lcccccccc}
\hline \multicolumn{1}{c}{ Perbandingan } & P1 & P3 & P4 & P5 & P6 & P7 & P8 & P9 \\
\hline Monokultur vs Tumpangsari & -7 & +1 & +1 & +1 & +1 & +1 & +1 & +1 \\
Pupuk-linier & 0 & -3 & -2 & -1 & 0 & +1 & +2 & +3 \\
Pupuk-kuadratik & 0 & +5 & 0 & -3 & -4 & -3 & 0 & +5 \\
\hline
\end{tabular}


Pola tanam monokultur dan tumpangsari juga berbeda pada pengamatan hasil jagung. Peningkatan dosis urea hingga $300 \mathrm{~kg} / \mathrm{ha}$ dapat meningkatkan hasil tanaman jagung secara linier, urea merupakan salah satu sumber Nitrogen sintesis. Nitrogen merupakan salah satu nutrisi penting untuk tanaman, yang diperlukan tanaman untuk memproduksi protein dan klorofil, menjaga efisiensi fotosintesis dan meningkatkan berat kering tanaman (Subedi, 2009).

Biji pada tanaman jagung yang ditanam secara monokultur lebih banyak (menutup tongkol secara sempurna) sedangkan pada tanaman tumpangsari tongkol tanaman banyak yang kosong (Gambar 1). Hal ini diduga karena terjadi persaingan baik untuk cahaya, unsur hara dan air untuk jagung pada tanaman tumpangsari.

Hasil tanaman jagung yang ditanam secara monokultur yaitu 2,6 t/ha dan hasil tumpangsari jagung rata-rata yaitu $1,7 \mathrm{t} / \mathrm{ha}$. Hal ini selain dipengaruhi oleh pola tanam juga dipengaruhi oleh pemupukan dan lingkungan tanam. Data curah hujan dari Politeknik Negeri Lampung menunjukkan bahwa rata-rata curah hujan pada bulan Agustus hingga November yaitu 89,95 $\mathrm{mm} /$ bulan (Tabel 2). Menurut Prihatman (2000), curah hujan optimal yang diperlukan untuk tanaman jagung yaitu $150-200 \mathrm{~mm} /$ bulan. Hal ini menyebabkan pertumbuhan tanaman terhambat karena kurangnya air untuk proses fotosintesis jagung.

Hasil analisis tanah menunjukkan bahwa $\mathrm{N}$ tersedia pada tanah sebelum penelitian yaitu $0,13 \%$ ini berarti ketersediaan $\mathrm{N}$ dalam tanah rendah (Tabel 3), analisis setelah penelitian menunjukkan terjadi

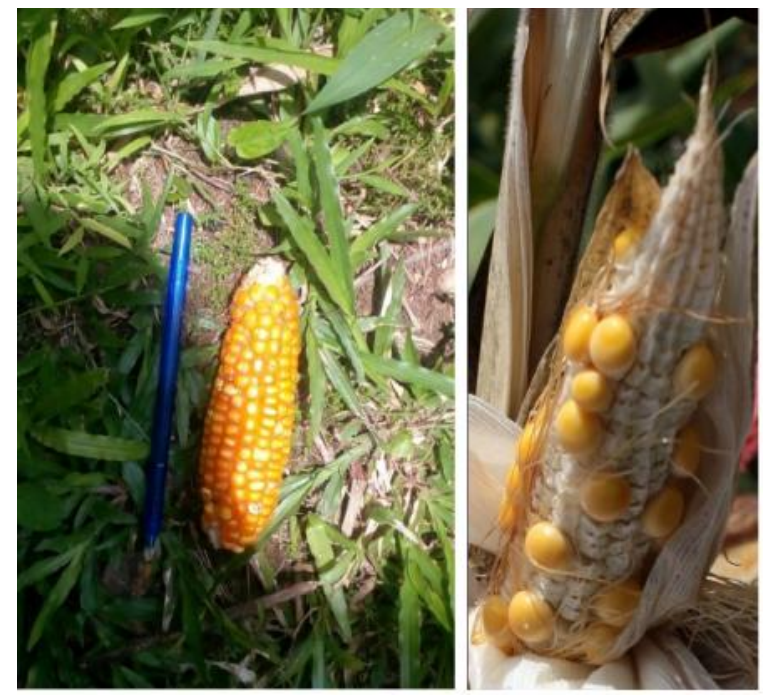

Gambar 1. Tongkol jagung yang ditanam secara a) monokultur b) tumpangsari. peningkatan $\mathrm{N}$ tersedia dalam tanah, hal ini diduga karena tanaman tidak bisa menyerap $\mathrm{N}$ dengan optimal karena kondisi lingkungan yang kering (Tabel 4).

Komponen hasil kacang tanah. Pola tanam monokuktur dan tumpangsari tidak berbeda pada jumlah polong total kacang tanah tetapi berbeda terhadap jumlah cabang produktif, jumlah polong isi, bobot 100 butir kacang tanah, dan hasil kacang tanah (Tabel 5).

Menurut Herlina (2011), cabang adalah tempat tumbuhnya daun, bunga, dan buah sehingga cabang merupakan indikasi terhadap produksi tanaman. Semakin banyak jumlah cabang produktif yang terdapat pada tanaman maka hasil tanaman semakin tinggi, hal ini karena genofora yang terletak di cabang tanaman dapat berkembang jika dilakukan pembumbunan, sedangkan untuk jumlah polong total yang banyak belum tentu dapat meningkatkan hasil tanaman. Hal ini diduga karena polong total yang ada pada tanaman tidak semuanya berkembang dengan baik, beberapa polong kacang tanah tidak berisi dan ada polong yang masih muda saat kacang tanah dipanen sehingga polong total kacang tanah tidak menghasilkan polong isi yang yang dapat meningkatkan hasil tanaman kacang tanah.

Tumpangsari jagung dan kacang tanah berpengaruh nyata terhadap bobot 100 butir kacang tanah dan hasil kacang tanah. Bobot 100 butir dan hasil kacang tanah yang ditanam secara monokultur lebih tinggi dibanding dengan bobot 100 butir dan hasil kacang tanah yang ditanam secara tumpangsari, Ahmad, Mezori dan Duhoky (2008) menyatakan bahwa pada pola tanam monokultur dan tumpangsari yang telah dilakukan, pola tanam tumpangsari berpengaruh nyata dalam meningkatkan bobot 100 butir biji kacang tanah.Bobot 100 butir tanaman kacang tanah yang ditanam secara tumpangsari lebih tinggi, hal ini diduga karena pada tanaman monokultur tidak terjadi persaingan antar tanaman kacang tanah sehingga monokultur kacang tanah bobot 100 butirnya lebih tinggi.

Pemberian urea juga berpengaruh terhadap peningkatan hasil kacang tanah, yaitu masih terjadi peningkatan hasil kacang tanah hingga penambahan dosis pupuk $300 \mathrm{~kg}$ urea/ha. Ahmad, Mezori dan Duhoky (2008) menyebutkan bahwa hasil dari kacang tanah berbeda nyata seiring dengan pemberian dosis pupuk urea yang berbeda. Hasil monokultur kacang tanah yaitu 1,07 t/ha dan hasil tumpangsari kacang tanah rataratanya adalah $0,42 \mathrm{t} / \mathrm{ha}$.

Rukmana (1998) menyatakan bahwa, daerah yang memiliki curah hujan $67-108 \mathrm{~mm} /$ bulan merupakan daerah yang baik untuk budidaya tanaman kacang tanah. Pada saat dilaksanakan penelitian curah hujan yang ada yaitu $89,95 \mathrm{~mm} /$ bulan (Tabel 2), namun penyebaran 
Tabel 2. Data curah hujan Agustus-Desember 2014

\begin{tabular}{|c|c|c|c|c|c|}
\hline \multirow{2}{*}{ Tanggal } & \multicolumn{5}{|c|}{ Curah Hujan (mm/hari) } \\
\hline & Agustus & September & Oktober & November & Desember \\
\hline 1 & 0 & 0 & 0 & 0 & 10,4 \\
\hline 2 & 0 & 0 & 0 & 0 & 0 \\
\hline 3 & 15,1 & 0 & 0 & 0 & 13,4 \\
\hline 4 & 2,0 & 0 & 0 & 0 & 0 \\
\hline 5 & 4,8 & 0 & 0 & 0 & 0 \\
\hline 6 & 5,4 & 0 & 0 & 8,5 & 0 \\
\hline 7 & 1,3 & 0 & 0 & 0 & 37,4 \\
\hline 8 & 0 & 0 & 0 & 0 & 14,8 \\
\hline 9 & 0 & 0 & 0 & 0 & 1,6 \\
\hline 10 & 0 & 0 & 0 & 0 & 0 \\
\hline 11 & 5,9 & 0 & 0 & 6,3 & 0 \\
\hline 12 & 4,6 & 0 & 0 & 0 & 0 \\
\hline 13 & 11,4 & 0 & 0 & 29,5 & 42,3 \\
\hline 14 & 10,5 & 0 & 1,5 & 0 & 5,0 \\
\hline 15 & 62,9 & 0 & 0 & 0,4 & 54,8 \\
\hline 16 & 0 & 0 & 0 & 0 & 0 \\
\hline 17 & 3,5 & 0 & 0 & 2,0 & 1,5 \\
\hline 18 & 0 & 0 & 0 & 0 & 0 \\
\hline 19 & 33,8 & 0 & 0 & 0 & 35,2 \\
\hline 20 & 0 & 0 & 0 & 0 & 10,7 \\
\hline 21 & 0 & 0 & 6,1 & 1,1 & 12,0 \\
\hline 22 & 0 & 0 & 0 & 7,0 & 48,7 \\
\hline 23 & 0 & 0 & 0 & 34,1 & 7,8 \\
\hline 24 & 0 & 0 & 0 & 0 & 58,3 \\
\hline 25 & 60,0 & 0 & 0 & 2,5 & 26,2 \\
\hline 26 & 0 & 0 & 23,4 & 0 & 15,0 \\
\hline 27 & 0 & 0 & 5,7 & 6,8 & 0 \\
\hline 28 & 0 & 0 & 0 & 0 & 0 \\
\hline 29 & 0 & 0 & 0 & 0 & 0 \\
\hline 30 & 0 & 0 & 0 & 3,7 & 3,5 \\
\hline 31 & 0 & 0 & 0 & 0 & 6,9 \\
\hline Jumlah (mm) & 221,2 & 0 & 36,7 & 101,9 & 405,5 \\
\hline HH (hari) & 13 & 0 & 4 & 11 & 19 \\
\hline Rerata (mm/hari) & 17,0 & 0 & 9,2 & 9,3 & 21,3 \\
\hline Keterangan & $\begin{array}{l}\text { u tanam } \\
\text { u panen }\end{array}$ & & & & \\
\hline
\end{tabular}

Sumber: Stasiun Cuaca Politeknik Negeri Lampung (2014)

curah hujan per hari tidak merata, pada awal tumbuh kacang tanah hingga tanaman mulai berbunga tidak turun hujan sama sekali sehingga polong yang terbentuk hanya sedikit.

\section{KESIMPULAN}

Dari hasil penelitian dapat dismipulkan bahwahasil tanaman yang ditanam secara monokultur lebih tinggi dibanding tanaman tumpangsari,rata-rata hasil tanaman jagung yang ditanam secara tumpangsari yaitu 1,69 t/ha dan tanaman kacang tanah yang ditumpangsarikan rataratanya yaitu $0,42 \mathrm{t} / \mathrm{ha}$, tanaman jagung yang ditanam secara monokultur hasilnya 2,61 ton/ha dan hasil kacang tanah yang ditanam monokultur yaitu 1,07 t/ha. Hasil tumpangsari tertinggi yaitu pada pemupukan urea 300 $\mathrm{kg} / \mathrm{ha}$ dengan hasil jagung 2,57 t/ha, dan kacang tanah $0,46 \mathrm{t} / \mathrm{ha}$ (Tabel 7). Belum diperoleh dosis pupuk urea yang optimum untuk jagung yang ditumpangsarikan dengan kacang tanah. 
Tabel 3. Data analisis tanah sebelum ditanami jagung dan kacang tanah

\begin{tabular}{lll}
\hline Deskripsi & \multicolumn{1}{c}{ Ketersediaan } & \multicolumn{1}{c}{ Keterangan } \\
\hline N tersedia & $0,13 \%$ & Rendah \\
P tersedia & $7,95 \mathrm{ppm}$ & Rendah \\
K dd & $0,31 \mathrm{ml} / 100$ gram & Sangat Rendah \\
pH tanah & 6,47 & Agak Masam \\
\hline
\end{tabular}

Tabel 4. Data analisis N-total tanah setelah ditanami jagung dan kacang tanah

\begin{tabular}{lcc}
\hline \multicolumn{1}{c}{ Kode sampel } & N-total $(\%)$ & Keterangan \\
\hline $\mathrm{P}_{1}($ Monokulturjagung) & 0,13 & Rendah \\
$\mathrm{P}_{2}$ (Monokulturkacangtanah) & 0,18 & Rendah \\
$\mathrm{P}_{3}(\mathrm{TS}$, Urea $0 \mathrm{~kg} / \mathrm{ha})$ & 0,17 & Rendah \\
$\mathrm{P}_{4}(\mathrm{TS}$, Urea $50 \mathrm{~kg} / \mathrm{ha})$ & 0,17 & Rendah \\
$\mathrm{P}_{5}(\mathrm{TS}$, Urea $100 \mathrm{~kg} / \mathrm{ha})$ & 0,17 & Rendah \\
$\mathrm{P}_{6}(\mathrm{TS}$, Urea $150 \mathrm{~kg} / \mathrm{ha})$ & 0,17 & Rendah \\
$\mathrm{P}_{7}(\mathrm{TS}$, Urea $200 \mathrm{~kg} / \mathrm{ha})$ & 0,17 & Rendah \\
$\mathrm{P}_{8}(\mathrm{TS}$, Urea $250 \mathrm{~kg} / \mathrm{ha})$ & 0,17 & Rendah \\
$\mathrm{P}_{9}(\mathrm{TS}$, Urea $300 \mathrm{~kg} / \mathrm{ha})$ & 0,17 & Rendah
\end{tabular}

Tabel 5. Pengaruh tumpangsari jagung dengan kacang tanah terhadap komponen hasil kacang tanah

\begin{tabular}{llllll}
\hline Perbandingan & \multicolumn{5}{c}{ Signifikansi } \\
& \multicolumn{1}{c}{1} & \multicolumn{1}{c}{2} & \multicolumn{1}{c}{3} & \multicolumn{1}{c}{4} & \multicolumn{1}{c}{5} \\
\hline Mono vs TS & $*(-0,09)$ & tn $(-6,17)$ & $*(-8,92)$ & $*(-8,42)$ & $*(-0,65)$ \\
P-linier & tn & tn & tn & tn & tn \\
P-kuadratik & tn & tn & tn & tn & tn \\
\hline
\end{tabular}

Tabel 7. Hasil panen jagung dan kacang tanah (t/ha)

\begin{tabular}{ccc}
\hline Perlakuan & Jumlah & Jumlah \\
\hline P1 & 7.83 & - \\
P2 & - & 3.22 \\
P3 & 3.05 & 1.13 \\
P4 & 4.15 & 1.06 \\
P5 & 4.37 & 1.27 \\
P6 & 4.80 & 1.27 \\
P7 & 5.69 & 1.41 \\
P8 & 6.00 & 1.32 \\
P9 & 7.70 & 1.39 \\
Jumlah & 43.59 & 12,07 \\
\hline
\end{tabular}




\section{DAFTAR PUSTAKA}

Ahmad, Z H. Mezori M, dan Duhoky. 2008. Effect of Intercropping System and Nitrogen Fertilizer on Yield, Yield Componen of Corn (Zea Mays L.) and Peanut (Arachis Hypogaea L.) J. Dohuk Univ. 11 (1): 2-4

Amjadian, M. Naser L M. Farshadfar dan Mehranoosh G. 2013. Study Of Intercropping Corn and Soybean in Various Planting Dates. J. Of Agriculture and Crop Sciences. 5 (20): 23652371

Ezward, Chairil. 2010. Uji Pola Tanam Antara Varietas Jagung Dan Varietas Kedelai Dan Pengaruh Efisiensi Dosis Imbangan N, P Dan K Terhadap Pertumbuhan Dan Produksi Jagung (Zea mays) dan Kedelai (Glycine max L.). (Tesis). Universitas Islam Riau. 109 hlm.

Gliessman, Stephen. 2007. Multiple Cropping System: A Basis for Developing an Alternative Agricculture. University of California. 70-83

Gofar, Nuni. 2015. Pupuk dan Pemupukan di Lahan Suboptimal. Jakarta : Polimedia Publishing. Hlm 45 dan 86

Herlina, 2011. Kajian Variasi Jarak Dan Waktu TanamJagung Manis Dalam Sistem Tumpang SariJagung Manis (Zea mays saccharata Sturt) dan KacangTanah (Arachis hypogaea L). (Artikel). Universitas Andalas. $39 \mathrm{Hlm}$.

Muyassir. 2013. Respon Jagung Tongkol Ganda (Zea mays L.) terhadap Pemupukan Urea dan Kompos. J. Manajemen Sumberdaya Lahan 2 (3): $250-254$
Nafziger, Emerson. 2007. Cropping System. Illinois Agronomy Handbook: Departement of Crop science. Hlm 49-50.

Prihatman, kemal. 2000 . Budidaya Jagung. Cv Nuansa Aulia: Bandung. Hlm 10-11.

Rukmana, Rahmat. 1998. Kacang Tanah. Kanisius :Yogyakarta. Hlm 21.

Sarjito dan Hartanto. 2007. Respon Tanaman Jagung TerhadapAplikasi Pupuk Nitrogen Dan Penyisipan Tanaman Kedelai. J. Penelitian dan Informasi Pertanian “Agrin” Vol. 11 (2): 130137

Subedi KD dan B. L. Ma. 2009. Corn Crop Production : growth, Fertilization and Yield. Canada: Nova Science Publishers. $84 \mathrm{Hlm}$.

Sumarno dan Unang G. K .2010. Kemelaratan bagi Petani Kecil di Balik Kenaikan Produktivitas Padi. Dimuat dalam Tabloid Sinar Tani No. 3335 Tahun XL, Hlm 18.

Warsana. 2009. Introduksi Teknologi Tumpang Sari Jagung Dan Kacang Tanah. Dimuat dalam Tabloid Sinar Tani, 25 Februari 2009.

Zhang, Jin. Zhao H L. Kun-Li. Wei-Huang dan Lian H S. 2012. Nitrogen Use Efficiency under Different Field Treatments on Maize Fields in Central China: A Lysimeter and N Study. Journal of Water Resource and Protection, 12 (4): 590-596 